\title{
Irreversible Dilated Cardiomyopathy After Abuse of Anabolic Androgenic Steroids: A Case Report and Literature Review
}

\author{
G Angelini*, P Pollice, ME Lepera, S Favale and C Caiati \\ Institute of Cardiovascular Disease, Department of Emergency and Organs Transplantations, Italy \\ *Corresponding author: Gianmarco Angelini MD, Department of Emergency and Organs Transplantations, Institute of \\ Cardiovascular Disease, University Hospital Policlinico of Bari, P.zza G. Cesare 11, CAP 70122, Bari, Italy
}

ARTICLE INFO

Received: 㓞 September 23, 2019

Published: 蔧October 03, 2019

Citation: G Angelini, P Pollice, ME Lepera, $S$ Favale and C Caiati. Irreversible Dilated Cardiomyopathy After Abuse of Anabolic Androgenic Steroids: A Case Report and Literature Review. Biomed J Sci \& Tech Res 21(4)-2019. BJSTR. MS.ID.003648.

Keywords: Dilated Cardiomyopathy; Heart Failure; Anabolic Androgenic Steroids; Diastolic Dysfunction; Cardiotoxicity

\begin{abstract}
Illicit usage in athletes of androgenic anabolic steroids, such as testosterone and its derivatives, can cause myocardial dysfunction, that is usually reversible after the end of the abuse. However, in some cases myocardial dysfunction can be severe and irreversible for reasons that are notclear. We report the case of a 31-year-old patient, bodybuilder, who came to our attention for acute heart failure secondary to a dilated cardiomyopathy, with severe and irreversible left ventricular systolic dysfunction (LVEF 23\%). Instrumental and laboratory examinations excluded myocarditis and coronary artery disease as a possible etiology of the left ventricular systolic dysfunction. The patient had previously taken different types of androgenic anabolic steroids (testosterone and derivatives), for almost twelve years and also growth hormone (GH) for 1 year, and never stopped hard exercise training throughout in order to improve his performance as a bodybuilder. He had been diagnosed with left ventricular systolic dysfunction, symptomatic for heart failure (NYHA class II-III), about six months after cessation of the abuse and the severe $\mathrm{LV}$ dysfunction did not reverse. We believe that the abuse of steroids may be the cause of our patient's left ventricular dysfunction, that became worse and irreversible due to many years of usage, in association with intense physical training and GH; our hypothesis is strengthened by experimental studies in animals and autopsy immunohistochemical studies demonstrating a direct cardiotoxicity of anabolic androgenic steroids. The possible etiologic mechanism underlying acute and chronic cardiotoxicity in humans of these substances in humans warrants closer clinical investigation.
\end{abstract}

\section{Introduction}

Numerous athletes make use of anabolic-androgenic steroids (AASs), the synthetic derivatives of the male hormone testosterone, to increase and strengthen muscle mass, even if this is illegal but impossible to control. The effect of abuse of these hormones on the body and in particular on the heart is still not entirely known. These substances can produce adverse effects on various organs, and in literature several cases of cardiac disease have been reported in athletes after previous abuse of AASs [1-13] documenting dilated cardiomyopathy (DCM). However only few of them have shown irreversible DCM $[1,6,8,13]$. We report the case of a 31-yearold white male, bodybuilder, who had previously used AASs. He presented to our attention with dilated cardiomyopathy and severe irreversible left ventricular systolic dysfunction. We focused on the mechanism on AASs induced irreversible LV dysfunction.

\section{Case Report}

The patient was a 31-year-old man, bodybuilder, with no family history of cardiac disease and no cardiovascular risk factors. When the patient came to our attention, he had received a diagnosis of dilated cardiomyopathy (undocumented) about one year before and started treatment with beta-blockers and diuretics; he then spontaneously suspended the therapy after a few months. He admitted having previously taken high doses of various AASs to increase his muscle mass, including stanozolol, boldenonem, 
trenbolone, testosterone proprionate and enanthate. His abuse of these substances had lasted for twelve years, and he also took human growth hormone for 1 year. He had stopped taking these substances one year before he came to our attention, after the diagnosis of dilated cardiomyopathy. The patient presented at the emergency room of our hospital with worsening dyspnea and orthopnea, symptoms that had started two months before and showed an increasing trend. He was apyretic, blood pressure was $120 / 80 \mathrm{mmHg}$, the heart rate was $90 \mathrm{bpm}$, the respiration rate was 25 breaths/min and peripheral arterial oxygen saturation was $95 \%$.

Physical examination showed a muscular man, the apex beat was not evident, the jugular at baseline showed an absent $X$ ' descent with a positive hepato-jugular reflux and heart sounds were regular at the auscultation; there was also minimal ankle swelling and , bilateral basal crackling rattles were audible at lung auscultation. The ECG showed a sinus rhythm with a frequency of $88 \mathrm{bpm}$, signs of left atrial enlargement, a left axial deviation and negative T-waves on D1 and aVL and from V4 to V6; no previous recent ECG was available for comparison. Chest X-ray showed pulmonary edema and an acute bronchopneumonia focus. Transthoracic echocardiography (TTE) revealed a dilated cardiomyopathy with severe left ventricular systolic dysfunction (LVEF 23\% calculated with the Simpson biplane method) and dilatation (telediastolic diameter $79 \mathrm{~mm}$ ) with moderate uniform hypertrophy (Figure 1a \& 1b). There was grade II diastolic dysfunction (E/A waves ratio 1,9; E wave deceleration time $144 \mathrm{msec}$ ), "B-bump" on M-mode examination at the mitral valve level and an average $\mathrm{E} / \mathrm{e}$ ' at tissue doppler analysis at the upper limit of the "grey zone": 14 (Figure 2a-2d); global longitudinal peak systolic strain (GLPSS) was -7,4\%; the left atrium was dilated; the right ventricle was dilated, slightly hypocontractile (tricuspidal annular plane systolic excursion, TAPSE, $16 \mathrm{~mm}$ ) with a dilated right atrium; the inferior cava vein showed a normal dimension and collapsibility.

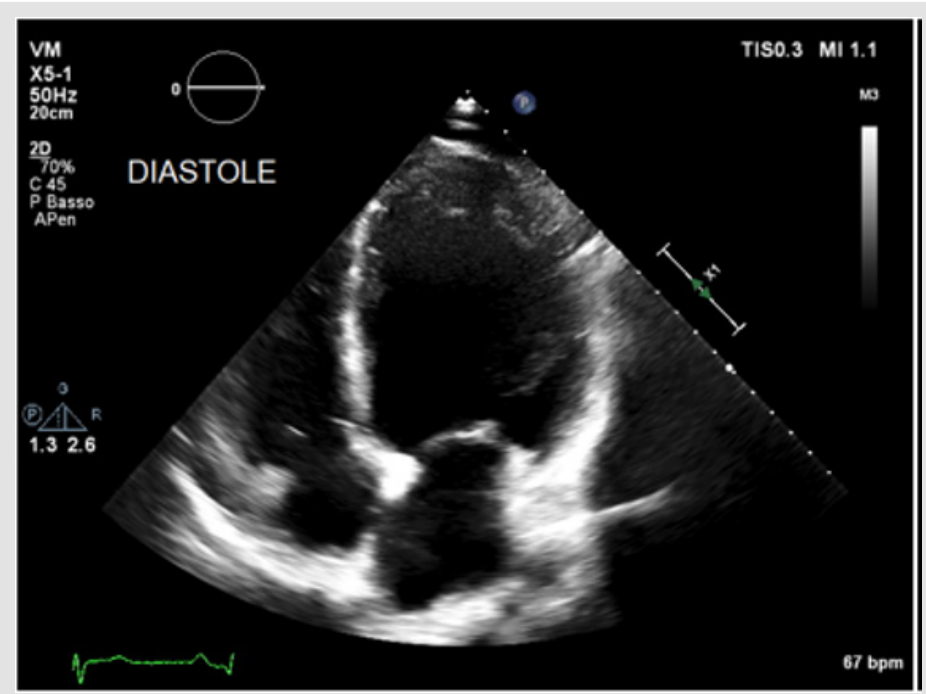

Figure 1a: Transthoracic echocardiography in the acute phase showing significant left ventricular dilatation (EDV $269 \mathrm{ml})$ and systolic dysfunction (LVEF 23\% calculated with the Simpson biplane method): apical 4-chamber views in telediastole.

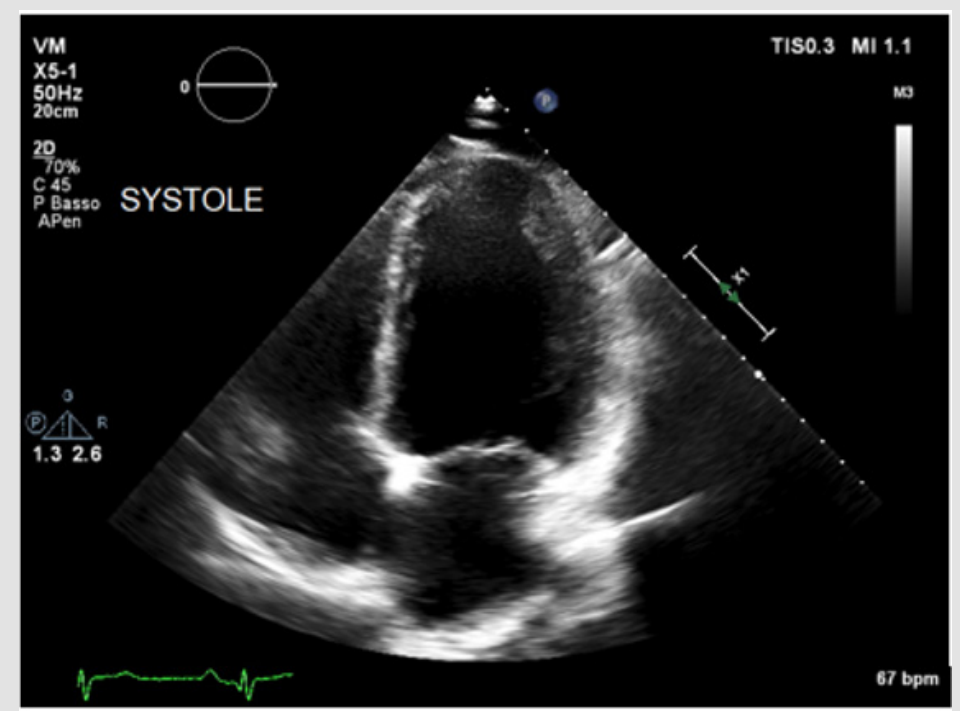

Figure 1b: EDV: end diastolic volume; LVEF: left ventricular ejection fraction. 


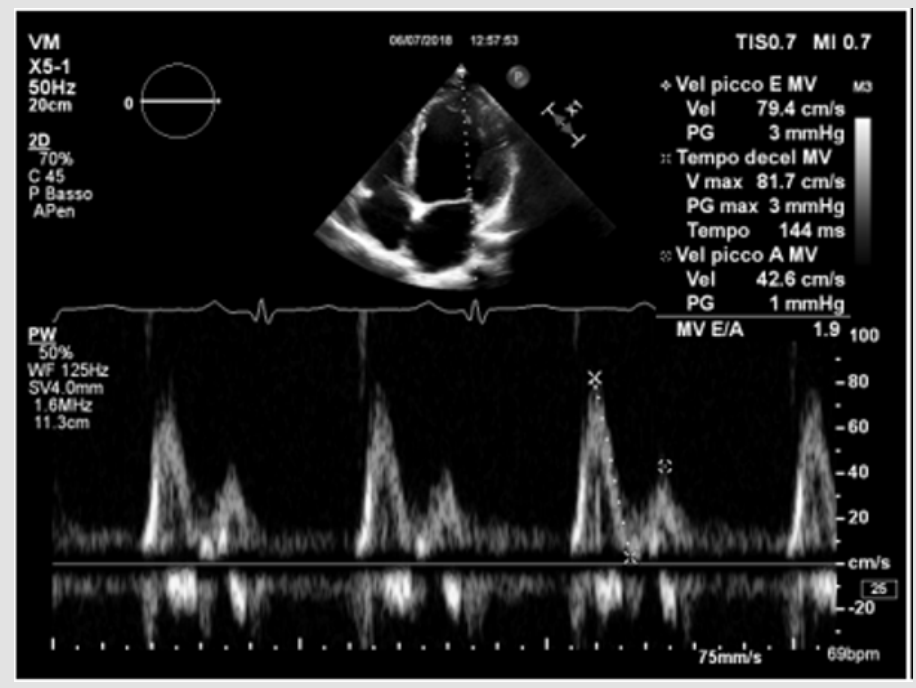

Figure 2a: Evaluation of left ventricular diastolic function showing grade II diastolic dysfunction in the acute phase: a mitral inflow pattern with E/A waves ratio 1.9.

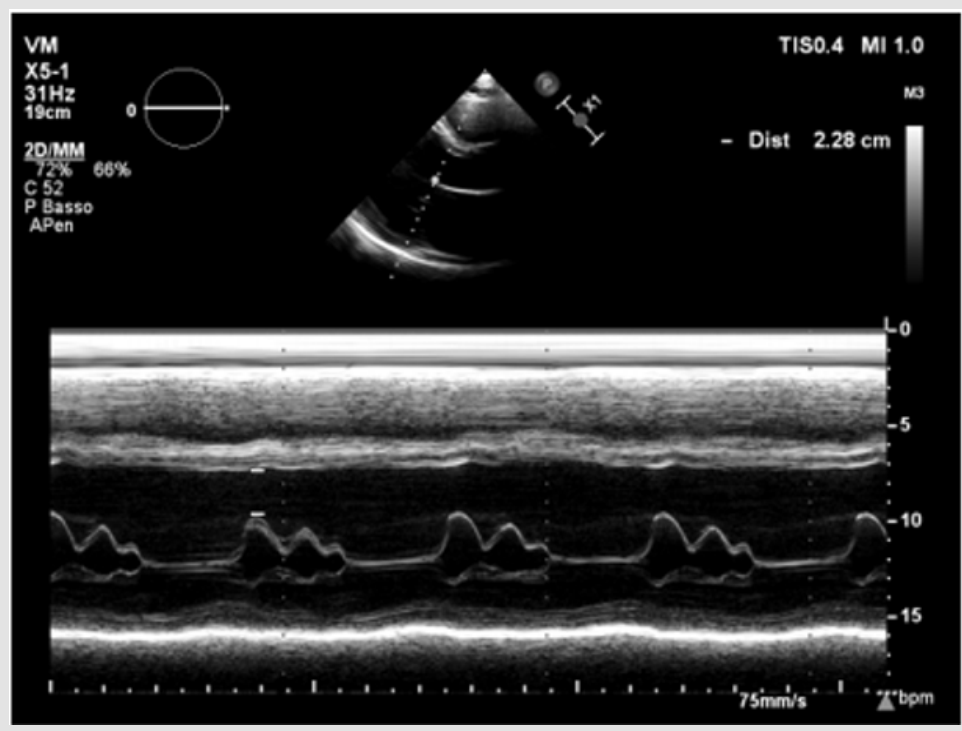

Figure 2b: Major “B-bump" on M-mode examination at mitral valve level.

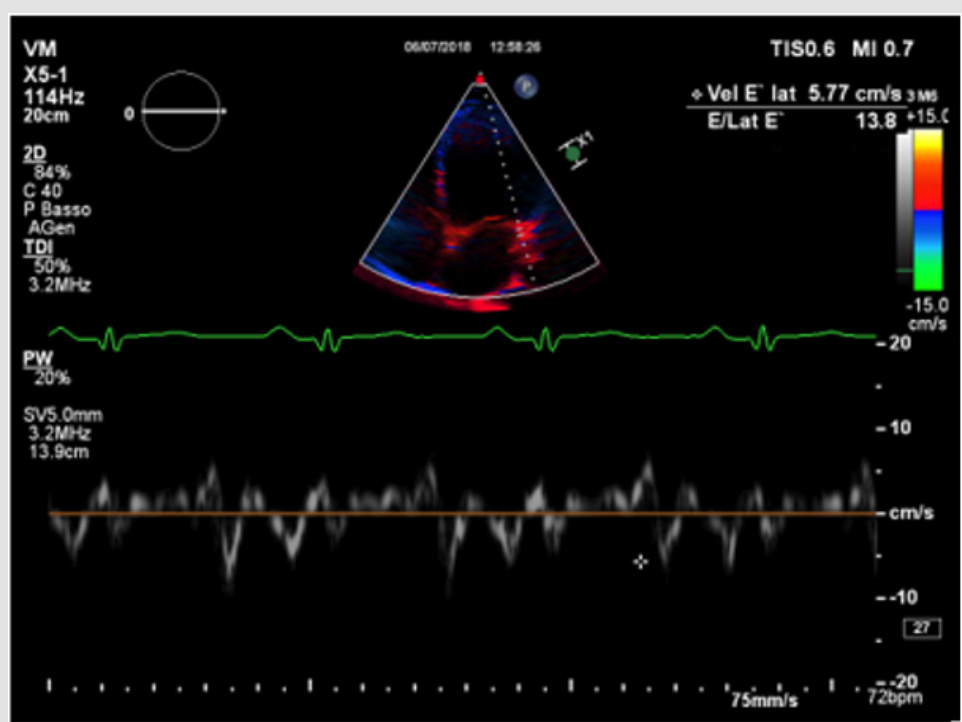

Figure 2c: An average E/e' ratio at TDI analysis at basal septal and lateral level of 14 (grey zone). 


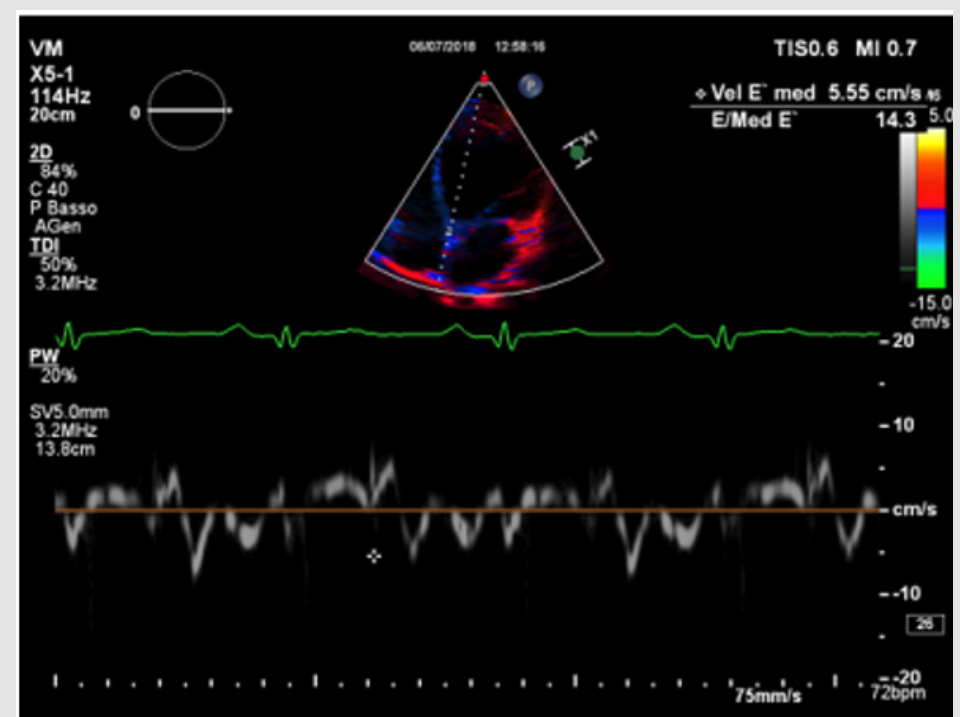

Figure 2d.

Laboratory tests showed increased leucocytes, a mild increase of red blood cells and hematocrit (hemoglobin: $16.7 \mathrm{~g} /$ $\mathrm{dl}$, hematocrit: 53.3\%), mildly increased systemic inflammatory markers (C-reactive protein: $13.2 \mathrm{mg} / \mathrm{l}$ ), moderate renal failure (eGFR: $61 \mathrm{~mL} / \mathrm{min}$ ). A peak troponin measurement showed a value of $0.118 \mathrm{ng} / \mathrm{ml}$ (our hospital cut-off value is $0.045 \mathrm{ng} /$ $\mathrm{mL})$, NT-proBNP was elevated $(1810 \mathrm{pg} / \mathrm{mL})$ and total serum cholesterol was $191 \mathrm{mg} / \mathrm{dl}$, with LDL $142 \mathrm{mg} / \mathrm{dl}$ and HDL 14 mg/dl. Virological tests were negative. The patient was promptly treated with intravenous diuretics, antibiotic and therapy for heart failure was also started. After stabilization, the patient underwent cardiac magnetic resonance (CMR) imaging with gadolinium contrast that highlighted a small area of late gadolinium enhancement (LGE) at the inferior basal septum level and ruled out the presence of myocardial edema. It also confirmed significant dilatation and left ventricular systolic dysfunction (LVFE: 18\%; telediastolic volume $388 \mathrm{~mL}$ indexed $155 \mathrm{~mL} / \mathrm{m}^{2}$, parietal mass FD $238 \mathrm{gr}$, telediastolic diameter 56 mm, telesystolic volume $202 \mathrm{~mL}$, indexed /BSA $80 \mathrm{~mL} /$ $\mathrm{m}^{2}$ ), right ventricular systolic dysfunction (RVFE: 22\%). Abdominal ultrasound highlighted mild hepatic steatosis with hepatomegaly. Coronary computed tomography ruled out coronary artery disease. After about 40 days, an echocardiographic evaluation showed no functional improvement. In view of the severe left ventricular systolic dysfunction and of the lack of improvement, we decided to implant a subcutaneous implantable-cardioverter-defibrillator (S-ICD).

\section{Discussion}

Our case highlights an interesting presentation of a dilated cardiomyopathy with acute decompensated heart failure one year after cessation of anabolic steroids in a patient who had performed intensive physical training, and showed no improvement of the ejection fraction after cessation of the abuse and initiation of conventional heart failure therapy. In literature there are several reports documenting AAS-induced cardiotoxicity and in particular DCM [1-13] (Table 1) although few of them indicate irreversible effects on cardiac muscle performance $[1,6,8,13]$ Table. We believe that what can happen in irreversible myocytes damage like in ours patient or even in fatal cases [14,15], is a more profound damage to the myocytes that can be caused by the synergism of AAS, possibly at high dosage and for a prolonged span of time with other factors that enhance the AAS damage, first of all strenuous exercise training. We will examine first the AAS general toxic effect mechanisms on cardiac myocytes and then the AAS synergism with strenous exercise and with other potential myocites damaging factors like the growth hormone (GH).

$\underline{\text { Table 1: }}$ Literature regarding AASs toxic effect on left ventricular function.

\begin{tabular}{|c|c|c|c|c|c|c|c|}
\hline $\begin{array}{l}\text { Authors and } \\
\text { year }\end{array}$ & Age & Cardiomyopathy & $\begin{array}{c}\text { Cardiac } \\
\text { Function } \\
\text { Parameters }\end{array}$ & $\begin{array}{l}\text { Other Associated } \\
\text { Findings }\end{array}$ & Last Use of AAS & $\begin{array}{l}\text { Duration } \\
\text { of Use }\end{array}$ & Outcome \\
\hline $\begin{array}{l}\text { Schollert and } \\
\text { Bendixen [1] }\end{array}$ & 33 & $\begin{array}{c}\text { Hypertrophy + LV } \\
\text { dil/dysf }\end{array}$ & UNK & $\begin{array}{l}\text { Atrial flutter with two- } \\
\text { toone block }\end{array}$ & $\begin{array}{c}\text { Three weeks } \\
\text { prior }\end{array}$ & UNK & Did not survive \\
\hline $\begin{array}{l}\text { Nieminen et } \\
\text { al. [2] }\end{array}$ & 31 & $\begin{array}{l}\text { Hypertrophy + LV } \\
\text { dil/dysf }\end{array}$ & $\begin{array}{l}\text { LVEF: 14\% LVED } \\
79 \text { mm (severe) }\end{array}$ & $\begin{array}{l}\text { Second degree Mobitz } \\
\text { type one heart block }\end{array}$ & UNK & $\begin{array}{l}\text { Complete } \\
\text { recovery }\end{array}$ & $\begin{array}{l}\text { Complete } \\
\text { recovery }\end{array}$ \\
\hline Ferrera et al. [3] & 24 & Dilated & LVEF: 39\% & None reported & UNK & UNK & $\begin{array}{l}\text { After } 1 \text { month } \\
\mathrm{LVEF}=69 \%\end{array}$ \\
\hline Vogt et al. [4] & 21 & Dilated & $\begin{array}{l}\text { LVEF: } 20-30 \% \\
\text { LVED: } 80 \mathrm{~mm} \\
\text { (severe) }\end{array}$ & None reported & UNK & UNK & UNK \\
\hline
\end{tabular}




\begin{tabular}{|c|c|c|c|c|c|c|c|}
\hline $\begin{array}{c}\text { Clark and } \\
\text { Schofield [5] }\end{array}$ & 40 & Dilated & LVEF: $10-15 \%$ & Global hypokinesis & UNK & UNK & UNK \\
\hline $\begin{array}{l}\text { Ahlgrim and } \\
\text { Guglin, [6] }\end{array}$ & 41 & Dilated & $\begin{array}{l}\text { LVEF: } 18 \% \\
\text { LVED: } 67 \mathrm{~mm}\end{array}$ & Global hypokinesis & Two years prior & Six weeks & $\begin{array}{l}\text { No significant } \\
\text { recovery }\end{array}$ \\
\hline Youssef et al. [7] & 39 & Dilated & $\begin{array}{l}\text { LVEF: } 35 \% \\
\text { LVED: } 69 \mathrm{~mm}\end{array}$ & $\begin{array}{l}\text { Apical thrombus } \\
\text { formation }\end{array}$ & Current & & $\begin{array}{l}\text { Stabilized LVEF: } \\
40-45 \% \text { at three } \\
\text { month follow-up }\end{array}$ \\
\hline $\begin{array}{l}\text { Shamloul et } \\
\text { al. [8] }\end{array}$ & 37 & Dilated & $\begin{array}{l}\text { LVEF: } 35 \% \\
\text { LVED: } 69 \mathrm{~mm}\end{array}$ & $\begin{array}{l}\text { Multiple thrombi in } \\
\text { ventricles and stroke }\end{array}$ & Current & & $\begin{array}{l}\text { Did not } \\
\text { recover due to } \\
\text { complications }\end{array}$ \\
\hline Han et al. [9] & 30 & Dilated & $\begin{array}{l}\text { LVEF: } 35 \% \\
\text { LVED: } 69 \mathrm{~mm}\end{array}$ & $\begin{array}{l}\text { Atrial fibrillation w/ RVR } \\
\text { and global hypokinesis }\end{array}$ & $\begin{array}{l}\text { Six weeks } \\
\text { prior }\end{array}$ & $\begin{array}{l}\text { Six weeks } \\
\text { prior }\end{array}$ & $\begin{array}{l}\text { Stabilized LVEF: } \\
\qquad 63 \% \\
\text { at two-year } \\
\text { follow-up }\end{array}$ \\
\hline Placci et al. [10] & 25 & $\begin{array}{l}\text { Takotsubo (apical } \\
\text { ballooning) }\end{array}$ & LVEF: $40 \%$ & $\begin{array}{l}\text { Middle apical akinesia } \\
\text { and compensatory } \\
\text { hyperkinesia in basal } \\
\text { segments }\end{array}$ & Current & $\begin{array}{l}\text { Three } \\
\text { weeks }\end{array}$ & $\begin{array}{l}\text { Stabilized } \\
\text { and complete } \\
\text { recovery of } \\
\text { cardiac function }\end{array}$ \\
\hline $\begin{array}{l}\text { Sabzi and Faraji } \\
{[11]}\end{array}$ & 34 & Dilated & $\begin{array}{l}\text { LVEF: } 30 \% \\
\text { LVED: } 77 \mathrm{~mm}\end{array}$ & $\begin{array}{l}\text { Ventricular thrombus } \\
\text { formation. Akinetic } \\
\text { and thin septum and } \\
\text { apex with mild mitral } \\
\text { regurgitation }\end{array}$ & UNK & UNK & $\begin{array}{l}\text { Partial recovery } \\
\text { (LVEF: } 40-45 \% \\
\text { at three month } \\
\text { follow-up) }\end{array}$ \\
\hline Patel et al. [12] & 28 & Dilated & LVEF: $20 \%$ & $\begin{array}{c}\text { Severe mitral stenosis, } \\
\text { aortic regurgitation, and } \\
\text { left atrial mass }\end{array}$ & Current & Two years & Stabilized \\
\hline Ha et al. [13] & 73 & $\begin{array}{l}\text { Hypertrophy + LV } \\
\text { dysfunction }\end{array}$ & LVEF: $35-40 \%$ & VT & 3 decades prior & $\begin{array}{l}\text { Twenty } \\
\text { years }\end{array}$ & $\begin{array}{l}\text { LVEF did not } \\
\text { recover }\end{array}$ \\
\hline
\end{tabular}

Note: LV dil-dys: left ventricle dilation and dysfunction; LVED: left ventricular end diastolic diameter; LVEF: left ventricular ejection fraction; UNK: unknown; VT: ventricular tachycardia; shadowed rows: cases with irreversible left ventricular dysfunction.

Regarding the general AAS cardiac toxic effect AASs can have numerous cardiovascular side effects and they have a proven direct cardiotoxicity [16]. The mechanisms underlying this cardiotoxicity are still not properly understood, but some studies suggest that the adverse effects of AASs on cardiac muscle can be direct: in rat cardiomyocytes, AASs induce apoptotic cell death in a dose-dependent manner [17]. The apoptotic process may be triggered by a membrane receptor -second messenger cascades that increase polyamines which are known to mediate uncontrolled transmembrane $\mathrm{Ca}^{++}$flux and also by increasing intracellular $\mathrm{Ca}^{++}$via $\mathrm{Ca}^{++}$influx and $\mathrm{Ca}^{++}$mobilization from the sarcoplasmatic reticulum [17]. The uncontrolled increase of $\mathrm{Ca}^{++}$affects apoptotic mitochondrial membrane permeability and triggers the release of apoptogenic factors including caspase- 9 from damaged mitochondria [17]. This mechanism was confirmed by an in-vitro study on the cardiomyocytes ultrastructure of rodents after AASs exposure demonstrating mitochondria and myofibrils aberrations similar to those observed in the early stages of human heart failure [18].

Post-mortem studies have corroborated the apoptotic mechanism. In a post-mortem immunohistochemical study, histological analyses were performed on heart tissue of two bodybuilders: the analysis showed important myocytes and endothelial cells apoptotic alterations [14], after various years of abuse of methelonone and nandrolone; these body builders also had a history of very strenuous training that could have enhanced these histopathological alterations. The clinical consequence of this myocardial damage has been corroborated in numerous clinical studies. In athletes that routinely used AASs, the onset of a subclinical impairment of both systolic and diastolic myocardial function has been reported even several years after the cessation of the abuse [13] Table. A study comparing groups of athletes, users and non-users of AASs, showed significantly lower $\mathrm{e}^{\prime} / \mathrm{a}^{\prime}$ ratios at tissue Doppler imaging (TDI) analysis in users at both the basal interventricular septum and the left ventricular lateral wall (both $\mathrm{p}<0.01$ ) levels, in comparison with non-users; in addition, at strain rate imaging (SRI) analysis, peak systolic longitudinal left ventricular strain and strain rate were both significantly reduced at the mid interventricular septum and at the left ventricular lateral free wall level in users of AASs compared to non-users.

The severity of these subclinical alterations was directly correlated with the mean dosage [19] and duration of AASs abuse [20]. A recent cross-sectional cohort study compared a group of male weightlifters who had used AASs (86 men) in the last two years with a group (54 men) with no history of abuse: at transthoracic echocardiography AASs users demonstrated a relatively reduced left ventricular systolic function (mean \pm SD 
LVEF $=52 \pm 11 \%$ vs. $63 \pm 8 \% ; \mathrm{P}<0.001)$ and diastolic function $\left(\mathrm{E}^{\prime}=\right.$ $9.3 \pm 2.4 \mathrm{~cm} / \mathrm{s}$ vs. $11.1 \pm 2.0 \mathrm{~cm} / \mathrm{s} ; \mathrm{P}<0.001$ ). Additionally, AASs users had a greater coronary artery plaque volume than non-users at coronary computed tomography (CCT) analysis [21]. Our patient had a negative coronary computed tomography, probably due to his younger age compared to the patients of this study, despite the altered serum lipids. Regarding the synergistic effect of strenuous exercise with AAS, there are post-mortem autopsy studies that suggest that strenuous exercise combined with AAS destroys the mitochondria by triggering a caspase cascade that brings about cell death via a more intense apoptosis [17].

Then, the loss of cellular energy production causes chronic hypoxia of the cardiac muscle and cell death can ensue due to apoptosis rather than necrosis. In addition, nandrolone could act through blocking or down regulating the mechanism implicated in the improvement in antioxidant defense in animal during exercise as demonstrated in animals [22]. GH is another potential harmful substance when taken at high dosage for long periods of times as our patients did for almost 1 year. Concomitant use of AAS and GH further increased LV mass and associated with concentric remodeling of $\mathrm{LV}$ [23].

Although left ventricular contraction is impaired in congenital GH deficiency, long term GH excess leads to cardiac hypertrophy and decreased cardiac function [24]. Our case recalls another literature report of a 41 body-builder with severe and irreversible dilated cardiomyopathy that had taken AAS and GH (actually insulin-like growth factor- 1 that is an active metabolite of GH) for long periods of time in association with intense physical training; he did not have any other risk factors for DCM [6] Table. In our view when the myocyte damage is profound and appears irreversible after an initial therapy, other hidden factors should be searched for like heavy metal contamination of the myocardium (mercury in particular) as previously demonstrated in idiopathic dilated cardiomyopathy, that brings about enhanced oxidative stress and further damage of mitochondria [25]. Our patient did not have dental amalgama fillings [26] but ate fish regularly 1-2 times/week so potential mercury exposure was modest. A hair analysis could be of aid for chronic heavy metal toxicity screening [19]. Our patient also presented abnormal plasma lipoproteins and laboratory signs of hepatotoxicity: these are other possible side effects of anabolic steroids abuse [27]. Echocardiography can have an important role in the detection of subclinical systo-diastolic dysfunction in AASs users and can be a useful way to discourage the use of these substances in sportsmen, revealing initial forms of heart injury through SRI and TDI analysis [20].

\section{Conclusion}

Long abuse of AAS along with intense physical exercise and GH conjured up irreversibly damaged cardiac myocytes mainly by activating apoptotic mechanism rather than causing necrosis. The abuse of AAS and GH by athletes to improve their performance needs to be strictly controlled and forbidden in view of the possible onset of serious, potentially irreversible cardiovascular diseases. The cause-effect relationship between AASs abuse and the onset of heart failure and irreversible cardiotoxicity mechanisms warrant closer investigations.

\section{Author's Contribution}

Drs Angelini and Pollice gave the same contribution as first authors.

\section{Conflict of Interests}

none to declare.

\section{References}

1. Schollert PV, Bendixen PM (1993) Dilated cardiomyopathy in a user of anabolic steroids. Ugeskrift for laeger 155(16): 1217-1218.

2. Nieminen MS, Ramo MP, Viitasalo M, Heikkila P, Karjalainen J, et al. (1996) Serious cardiovascular side effects of large doses of anabolic steroids in weightlifters. Eur Heart J 17(10): 1576-1583.

3. Ferrera PC, Putnam DL, Verdile VP (1997) Anabolic Steroid Use as the Possible Precipitant of Dilated Cardiomyopathy. Cardiology 88(2): 218220.

4. Vogt AM, Geyer H, Jahn L, Schanzer W, Kubler W, et al. (2002) Cardiomyopathy associated with uncontrolled self-medication of anabolic steroids. Zeitschrift fur Kardiologie 91(4): 357-362.

5. Clark BM, Schofield RS (2005) Dilated Cardiomyopathy and Acute Liver Injury Associated with Combined Use of Ephedra, $\gamma$-Hydroxybutyrate, and Anabolic Steroids. Pharmacotherapy: The Journal of Human Pharmacology and Drug Therapy 25(5): 756-761.

6. Ahlgrim C, Guglin M (2009) Anabolics and Cardiomyopathy in a Bodybuilder: Case Report and Literature Review. Journal of Cardiac Failure 15(6): 496-500.

7. Youssef MYZ, Alqallaf A, Abdella N (2011) Anabolic androgenic steroidinduced cardiomyopathy, stroke and peripheral vascular disease. BMJ Case Reports.

8. Shamloul RM, Aborayah AF, Hashad A, Abd Allah F (2014) Anabolic steroids abuse-induced cardiomyopathy and ischaemic stroke in a young male patient. BMJ Case Reports.

9. Han HC, Farouque O, Hare DL (2015) Steroid-induced cardiomyopathy. Medical Journal of Australia 203(5): 226-227.

10. Placci A, Sella G, Bellanti G, Margheri M (2015) Anabolic androgenic steroid induced Takotsubo cardiomyopathy. BMJ Case Reports.

11. Sabzi F, Faraji R (2017) Large In-transient Left Ventricular Thrombus due to Anabolic Steroid-induced Cardiomyopathy. Indian J Crit Care Med 21(1): 51-54.

12. Patel M, Shere A, Ghali J (2018) Anabolic steroids induced cardiomyopathy. Journal of the American College of Cardiology 71(11): 2416.

13. Ha ET, Weinrauch ML, Brensilver J (2018) Non-ischemic Cardiomyopathy Secondary to Left Ventricular Hypertrophy due to Long-term Anabolicandrogenic Steroid Use in a Former Olympic Athlete. Cureus 10(9): 3313.

14. Cecchi R, Muciaccia B, Ciallella C, Di Luca NM, Kimura A, et al. (2017) Ventricular androgenic-anabolic steroid-related remodeling: an immunohistochemical study. Int J Legal Med 131(6): 1589-1595.

15. Frati P, Busardo FP, Cipolloni L, Dominicis ED, Fineschi V, et al. (2015) Anabolic Androgenic Steroid (AAS) related deaths: autoptic, histopathological and toxicological findings. Curr Neuropharmacol 13(1): 146-159. 
16. Luijkx T, Velthuis BK, Backx FJ, Buckens CF, Prakken NH, et al. (2013) Anabolic androgenic steroid use is associated with ventricular dysfunction on cardiac MRI in strength trained athletes. Int J Cardiol 167(3): 664-668.

17. Zaugg M, Jamali NZ, Lucchinetti E, Xu W, Alam M, et al. (2001) Anabolicandrogenic steroids induce apoptotic cell death in adult rat ventricular myocytes. Journal of Cellular Physiology 187(1): 90-95.

18. Behrendt H, Boffin H (1977) Myocardial cell lesions caused by an anabolic hormone. Cell Tissue Res 181(3): 423-426.

19. Nouioui MA, Araoud M, Milliand ML, Bessueille Barbier F, Amira D, et al (2018) Evaluation of the status and the relationship between essential and toxic elements in the hair of occupationally exposed workers. Environmental monitoring and assessment 190(12): 731.

20. D Andrea A, Caso P, Salerno G, Scarafile R, De Corato G, et al. (2007) Left ventricular early myocardial dysfunction after chronic misuse of anabolic androgenic steroids: a Doppler myocardial and strain imaging analysis. Br J Sports Med 41(3): 149-155.

21. Baggish Aaron L, Weiner Rory B, Kanayama G, Hudson James I, Lu Michael T, et al. (2017) Pope Harrison G. Cardiovascular Toxicity of Illicit Anabolic-Androgenic Steroid Use. Circulation 135(21): 1991-2002.

\section{ISSN: 2574-1241}

DOI: 10.26717/BJSTR.2019.21.003648

G Angelini. Biomed J Sci \& Tech Res

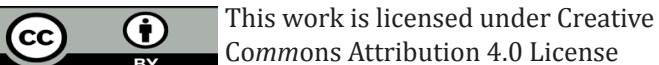

Submission Link: https://biomedres.us/submit-manuscript.php
22. Chaves EA, Pereira Junior PP, Fortunato RS, Masuda MO, de Carvalho $\mathrm{AC}$, et al. (2006) Nandrolone decanoate impairs exercise-induced cardioprotection: role of antioxidant enzymes. J Steroid Biochem Mol Biol 99(4-5): 223-230.

23. Karila TA, Karjalainen JE, Mantysaari MJ, Viitasalo MT, Seppala TA, et al. (2003) Anabolic androgenic steroids produce dose-dependant increase in left ventricular mass in power atheletes, and this effect is potentiated by concomitant use of growth hormone. Int J Sports Med 24(5): 337343.

24. Csanady M, Gaspar L, Hogye M, Gruber N (1983) The heart in acromegaly: an echocardiographic study. Int J Cardiol 2(3-4): 349-361.

25. Frustaci A, Magnavita N, Chimenti C, Caldarulo M, Sabbioni E, et al. (1999) Marked elevation of myocardial trace elements in idiopathic dilated cardiomyopathy compared with secondary cardiac dysfunction. J Am Coll Cardiol 33(6): 1578-1583.

26. Huggins HA (1993) It's all in your head. The link between mercury amalgama and illness: Paragon press, Honesdale, PA.

27. Achar S, Rostamian A, Narayan SM (2010) Cardiac and metabolic effects of anabolic-androgenic steroid abuse on lipids, blood pressure, left ventricular dimensions, and rhythm. Am J Cardiol 106(6): 893-901.

$\begin{array}{ll}\text { BIOMEDICAL } & \text { Assets of Publishing with us } \\ \text { RESEARCHES } & \text { - Global archiving of articles } \\ & \text { - Immediate, unrestricted online access } \\ & \text { - Rigorous Peer Review Process } \\ \end{array}$

